

\title{
INTERNATIONAL FINANCIAL REPORTING STANDARDS FOR SMALL AND MEDIUM ENTERPRISE (IFRS FOR SMES) AND THE STATEMENT OF ACCOUNTING STANDARDS (SAS): A COMPARATIVE STUDY
}

\author{
${ }^{1}$ Muotolu Peace, Chikwemma, ${ }^{2}$ Egungwu Ngozi, Ursula and ${ }^{3}$ Anichebe Alphonsus, Sunday \\ (Ph.D.)

\section{1,2,3 Faculty of Management Sciences, Chukwuemeka Odumegwu Ojukwu University, Igbariam Campus, Anambra State, Nigeria.}

Email: peacekafor@yahoo.co.uk, ngoziegungwu@yahoo.com, tesalfo@yahoo.com

\begin{abstract}
Purpose: Micro, small and medium-sized enterprises (SME) are the engines that propel the world economy; they are essential sources of jobs, they create entrepreneurial spirit and innovation in the economy and are thus crucial for fostering competitiveness and creativity. The objective of this study therefore, is to ascertain the need for International Financial Reporting Standard for Small and Medium Enterprises (IFRS for SMEs) instead of Statement of Accounting Standards (SAS), to ascertain the extent to which IFRS aids managements in attaining goals and objectives as well as improving its market share and to ascertain the challenges for Non-compliance (causes and penalties) with international financial reporting standard for Small and Medium Enterprises.
\end{abstract}

Methodology: Analysis of variance (ANOVA) was used to test hypothesis.

Results: The findings were; a major factor why IFRS is adopted by Nigeria is because other countries have adopted it, the size of entities to participate in IFRS for SMES varies, adopting a globally accepted financial reporting is relevant to small firms as they operate in a globalized world.

Policy recommendation: This study recommends that the IASB should ensure full implementation/compliance of IFRS for SME by companies that fall under that category, the cost of acquiring IFRS education should also be subsidized for small firms by major accounting regulatory bodies in Nigeria.

Keyword: small and medium scale enterprise, international financial reporting standard, statement of accounting standard. 


\section{INTRODUCTION}

International Financial Reporting Standards (IFRS) are a set of accounting standards developed by the International Accounting Standards Board (IASB) that is becoming the global standard for the preparation of public company financial statements. The objectives of any financial reporting is to affirmatively communicate with the users the true financial position of an enterprise in a summarized and standard form in order to facilitate their understanding for economic and related decision-making. To ensure that financial reporting meets these qualities, an acceptable accounting standard it needed and must be put in place and such standard should be seen as a principle-based rather than rule-based (Agoglica, Doupnik \&Tsakumis, 2011). But, it must relatively stable.

In Nigeria, statement of accounting standard (SAS) has mainly been the official standard in practice up to 2012 (for public interest enterprises) when imposition of the new international standard came to replace it. Report show that one key objective of the new standard according to the 2007 International Accounting Standard Board (IASB) and (2011) IFRS foundation is to develop, in the public interest provision for simplified self-contained set of accounting principles that are appropriate for smaller and non-listed/quoted companies.

Since the past decade, members of the accounting profession have been anticipating the adoption of the IFRS (Security and Exchange Commission, 2010 as cited in Winney, Marshall, Bander \&Swiger, 2010); this anticipation has promoted a lot of academic research on the subject in the world. Nigeria is not an exception. As a result of this, the International Financial Reporting Council of Nigeria (IFRCN) announced the transition date for adopting IFRS for SMEs in Nigeria to being from January 1, 2012. (Nigeria Accounting Standard Board, 2010). Since the official announcement of the of IFRS in the European union in 2002, accounting research has examined the process, especially the impact, progress and challenges it entails (Callao, Jarne, \& La'inez, 2007). However, most of the previous studies on adoption of international accounting standards by countries are country specific (Gyasi, 2010) and the focus of most literature have been larger firms, sometimes only listed or quoted firms (Anacoreta \& silva, 2005). The level of preparedness of Nigeria for adoption of IFRS for SMEs with regards to the roadmap announced by FRCN has not been empirically examined and established.

This study is therefore motivated by the desire to contribute to filling this observed knowledge gap as well as to explore the viability of the differences between IFRS and SAS, IFRS and NGAAP, Full IFRS and IFRS for SME's, Implementation, Benefit, Challenges and Solutions to Challenges of IFRS for SMEs in Nigeria. Report shows that even many listed companies who have adopted IFRS in Nigeria since 2012 still have issues in meeting deadlines for the submission of their annual reports such that the deadline had to be extended by one month (Nwachukwu, 2014), hence the need for this study. 


\section{THEORETICAL FRAMEWORK}

This study was based on the theory of the pure - impression - management model (PIMM) of accounting propounded by Keppler in 1995 (as cited by Ezeani\&Oladele, 2012). The theory states that accountability serves as a linkage construct by continually reminding people of the need to:

a) Act in accordance with the prevailing form and content of financial reporting.

b) Advance compelling, justification/excuses for conduct that deviate from the form and content of financial reporting.

Corporate reporting is an essential activity in the modern economic landscape in business environment replete business failure, bankruptcy news, lenders and investors pay attention to financial reports to distinguish companies experiencing economic distress from those that are profitable. These statements also help corporate leadership prevent losses resulting from litigation in case of inaccurate reporting.

Corporate financial reporting is a series that allows companies to record operating data and report accurate accounting statements at the end of each month and quarter, according to Duke University's, the Fuqua School of Business Bookkeepers record operating data by debiting and crediting financial accounts. Accountants prepare financial statements in accordance to corporate policies, Industry practices and regulatory guidelines.

The significance of corporate reporting can be evidence as it enables organizations to present accurate accounting statements. This practice helps firms conform to international financial reporting standards and the world gradually accepted accounting principles.

In the area of Corporate Reporting, which covers issues related to accounting, periodic reporting and storage of regulated information as well as auditing a lot of work has been done to have a uniform global standard as in International Accounting Standards (IASs), International Auditing Standards Requirement (IASR), International Public Sector Accounting Standards (IPSASs), International Financial Reporting Standards (IFRSs) etc.

\section{EMPIRICAL STUDIES}

Ekwem (2012) studied Small and medium scale enterprises development in Nigeria: constraints and policy options using Chi-Square The study determined, among others, that with the exclusion of lack of finance, the major constraints or challenges of SMEs ranked in descending order are inadequate managerial/board expertise, poor infrastructural facilities, inconsistencies in government policies, lack of financial records, multiple taxes and levies, etc. It also determined that lack of finance is a function of multiple problems and that the major sources of credit available for the financing SMEs in Nigeria are personal savings, family/friend support and commercial banks. Kanu, Onuha, Eguru; Gabriel Isu (2014) in their work IFRS for SMEs using Chi-square to analyse primary data, the result obtained from the perception of chartered accountants, users of financial statement and owners of SMEs show that SMEs are ready to adopt IFRS despite the challenges of SMEs in Nigeria. 
Aremu and Adeyemi (2011) studied Small and Medium Scale Enterprises as A Survival Strategy for Employment Generation in Nigeria Z-test was used and the results showed that SME sector also formed the vanguard of the modern enterprise sector and presents the propelling force of economic modernization and growth in Nigeria. They are important sector that need to be adequately factored into policy making and programme implementation in Nigeria. Odia and Ogiedu (2013) in their Theoretical work IFRS Adoption: Issues, Challenges and Lessons for Nigeria and other Adopters, they found out that IFRS is perceived as a high-quality accounting standard, compared to most local accounting standards, which can help to foster increased comparability of financial statements by investors. Globalization, increased border-listing, attraction of foreign investment and aids, and other institutional factors have been the motivating factors for IFRS adoption.

Adetula, Owolabiand Oyeoka (2014) in their Theoretical research work, adopting international financial reporting standards (IFRS) in Africa: benefits, prospects and challenges, their findings show that IFRS would be adopted by Nigeria because other countries have adopted them. IFRS is relevant to small organizations as they operate in a globalized world. IFRS for SMEs adoption process is currently plagued with different challenges that may distort the effect adoption and implementation of IFRS for SMEs in Nigeria. The level of preparation by SMEs in Lagos is not yet satisfactory. Gyasi (2010) studied Effect of better understanding of financial statement. Data was collected by questionnaire and analyzed using strapro software. The results show that the call for a better understanding in preparing financial statement using global benchmark should be appreciated.

Ezeani and Olaleye (2012) studied the adoption of international financial reporting standards (IFRS) to enhance financial reporting in Nigeria universities using mean scores and Z-Test. Their findings show that accountants and auditors should focus in discharging their duties. And as well a lot of implications are also involved. Mostly accountants, auditors, bursars, financial analyst, etc, are the personnel involve in the IFRS financial instruments. Abata (2015) researched on the impact of International financial reporting standards (IFRS) adoption on financial reporting practice in the Nigerian banking sector using a modified version of the Gray's Conservatism Index Gray Cardozzo (2008) and 'Comparability Index'. Results show that the quantitative differences in the financial reports prepared under NGAAP and IAS/IFRS are statistically significant.

Abata (2015) also studied the Impact of IFRS on Financial Reporting Practices in Nigeria(A case of KPMG) using Pearson Chi- square analysis and concluded that reports prepared under IFRSs enhanced best practices in a corporate organization (Pearson Chi-Square $=37.857$ ); financial statements prepared in line with IFRS provides greater benefits than the former GAAP (SAS) (Pearson Chi-Square $=75.763$ ); the compliance with IFRS promotes cross border investment and access to (Pearson Chi-Square $=63.128$ ); and compliance with IFRS will relatively improve the performance of companies (Pearson Chi-Square $=20.417$ ).

Akindele (2014) analyzed the impacts of international financial reporting standards adoption on financial statements: The case of Nigeria. A theoretical research, he concluded that IFRS should be included in the syllabus of accounting student in the tertiary institutions so that students will 
have the knowledge before entering into the labour market. Adetula, Owolabi and Oyeoka (2014) in their work; to explore the viability of the adoption of IFRS for SMEs in Nigeria. t-test was used, their findings were that IFRS would be adopted by Nigeria because other countries have adopted them. IFRS is relevant to small organizations as they operate in a globalized world. IFRS for SMEs adoption process is currently plagued with different challenges that may distort the effect adoption and implementation of IFRS for SMEs in Nigeria. That the level of preparation by SMEs in Lagos is not yet satisfactory.

\section{METHODOLOGY}

Population: The population of this research was 1118 active SMEs registered with the following Associations and Chambers of Commerce whose membership has a national spread.

1) National Association of Small and Medium Scale Enterprises (NASME) with nominal membership strength of over three thousand but with only about three hundred and forty seven (347) active members.

2) Lagos Chamber of Commerce \& Industry (LCCI) - Small and Medium Enterprises and Distributive Group with about five hundred and eighty two (482) in membership strength

3) Nigerian American Chamber of Commerce (NACC) - SME group of two hundred and eighty nine (289) members. The registered and active membership strength of these Associations and Chambers of Commerce stood at 1118 as at April 2016 as per the figures collected from the various secretariats of these Bodies.

A sample size of 294 was gotten using YaroYameni formular. A total number of 294 questionnaires were distributed. The respondents of these firms are Sole Proprietor, Partners of SMEs, staff of Private and Public Limited Companies, accountants of SMEs, internal auditors of SMEs, Chief executives, directors, and finance managers.

The research instrument contains 19 questions on IFRS for SMEs against which the respondents were asked to indicate their level of agreement upon a five point Likert scale (where $5=$ strongly agree, $4=$ agree, $3=$ undecided, $2=$ disagree and $1=$ strongly disagree). Each question number is subsequently referred to as Q1-Q19. The questionnaires were subjected to face and content validity. 
Measures of dispersion and percentages was used to analyze data collected while Analysis of variance was used to test hypothesis. It is derived $b$

Between group sum of square

Within group sum of square

formula for between group sum of squares

$\sum\left(\sum \mathrm{x}\right)^{2}-\left(\sum \mathrm{x}\right)^{2}$

Formula for within group sum of squares

$$
\sum \sum \mathrm{x}^{2}-\frac{\sum\left(\sum \mathrm{x}\right)^{2}}{\mathrm{n}}
$$

\section{DATA PRESENTATION AND ANALYSIS}

In order to prove the reliability of the responses three hypotheses were tested. A total number of 294 questionnaires were responded to and returned.

\section{Test of Hypothesis 1}

Ho1: There is no significant need for International Financial Reporting Standards for Small and Medium Enterprise in Nigeria.

Table 1: Test of Hypothesis 1

\begin{tabular}{|c|c|c|c|c|c|c|c|c|c|c|c|c|c|}
\hline \multicolumn{2}{|c|}{$\begin{array}{l}\text { Sole } \\
\text { proprietors }\end{array}$} & \multicolumn{2}{|c|}{ Partners } & \multicolumn{2}{|c|}{ Accountants } & \multicolumn{2}{|c|}{$\begin{array}{l}\text { Internal } \\
\text { auditors }\end{array}$} & \multicolumn{2}{|c|}{$\begin{array}{l}\text { Executive } \\
\text { directors }\end{array}$} & \multicolumn{2}{|c|}{$\begin{array}{l}\text { Finance } \\
\text { managers }\end{array}$} & \multicolumn{2}{|c|}{ other staff } \\
\hline X & $\mathrm{X}^{2}$ & $\mathrm{X}$ & $\mathrm{X}^{2}$ & $\mathrm{X}$ & $\mathrm{X}^{2}$ & $\mathrm{X}$ & $\mathrm{X}^{2}$ & $\mathrm{X}$ & $\mathrm{X}^{2}$ & $\mathrm{X}$ & $\mathrm{X}^{2}$ & $\mathrm{X}$ & $\mathrm{X}^{2}$ \\
\hline 67 & $\begin{array}{l}448 \\
9\end{array}$ & 23 & 529 & 327 & $\begin{array}{l}10692 \\
9\end{array}$ & 73 & 5329 & 80 & 6400 & 112 & $\begin{array}{l}1254 \\
4\end{array}$ & 361 & $\begin{array}{l}13032 \\
1\end{array}$ \\
\hline 40 & $\begin{array}{l}160 \\
0\end{array}$ & 11 & 121 & 90 & 8100 & 26 & 676 & 33 & 1089 & 34 & 1156 & 86 & 7396 \\
\hline 15 & 225 & 7 & 49 & 20 & 400 & 8 & 64 & 8 & 64 & 10 & 100 & 23 & 529 \\
\hline 10 & 100 & 13 & 169 & 35 & 1225 & 16 & 256 & 21 & 441 & 22 & 484 & 65 & 4225 \\
\hline 23 & 529 & 7 & 49 & 35 & 1225 & 12 & 144 & 20 & 400 & 8 & 64 & 51 & 2601 \\
\hline $\begin{array}{l}\sum x \\
=155\end{array}$ & $\begin{array}{l}\sum x 2 \\
= \\
6943\end{array}$ & $\begin{array}{l}\sum_{=} x \\
=61\end{array}$ & $\begin{array}{l}\sum x 2= \\
917\end{array}$ & $\begin{array}{l}\sum x \\
=507\end{array}$ & $\begin{array}{l}\sum \times 2= \\
11787 \\
9\end{array}$ & $\begin{array}{l}\sum x= \\
13 \\
5\end{array}$ & $\begin{array}{l}\sum x 2= \\
6469\end{array}$ & $\begin{array}{l}\sum x= \\
162\end{array}$ & $\begin{array}{l}\sum \times 2 \\
=839\end{array}$ & $\begin{array}{l}\sum x \\
=18\end{array}$ & $\begin{array}{l}\sum \times 2 \\
=143\end{array}$ & $\begin{array}{l}\sum x= \\
586\end{array}$ & $\begin{array}{l}\sum \mathrm{x} 2 \\
= \\
1450\end{array}$ \\
\hline
\end{tabular}


Table 1 (Contd.)

Sole

proprietors

$\mathrm{N} \quad 5$

$\sum \mathrm{x} \quad 155$

$\sum x^{2} \quad 24025$

$\sum x^{2} / \quad 4805$

$\mathrm{n}$

$\sum \sum \mathrm{x}=1791=\left(\sum \sum \mathrm{x}\right)^{2}=706995: .\left(\sum \sum \mathrm{x}\right)^{2} / \mathrm{n}=706995 / 35=20199.9$

Formula for between groups sum of squares

$\sum \underset{n}{\left(\sum x\right)^{2}}-\left(\sum x\right)^{2}$

.. $706995-20199.9=686795.1$

Formula for within group sum of squares

$$
\sum \sum \mathrm{x}^{2}-\sum\left(\sum \mathrm{x}\right)^{2}
$$

$706995-95099=611896$

Degree of freedom $(\mathrm{df})=\mathrm{K}-1$ (number of groups minus one)

$\therefore 7-1=6$

Degree of freedom (df) for within groups $=\mathrm{N}-\mathrm{K}$ (total number of respondents in the groups minus number of groups)

$\therefore 35-7=28$

Degree of freedom (df) for total variance $=\mathrm{N}-1$ (total number of respondents in the groups minus one). $\therefore .35-1=34$

Mean sum of squares (variance estimate)

$=\underline{686795.1}$

$6=114465.8$ 
Within group mean square

$$
\begin{aligned}
& =\underline{611896} \\
& 28=21853 \\
& F-\text { ratio }=\frac{1114465.8}{21853}=5.2
\end{aligned}
$$

\begin{tabular}{|c|c|c|c|c|}
\hline $\begin{array}{l}\text { source } \\
\text { variation }\end{array}$ & sum of squares & $\begin{array}{l}\text { Degree } \\
\text { freedom }\end{array}$ & 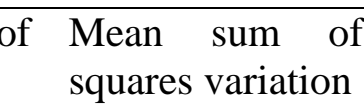 & $\mathrm{F}$ \\
\hline Between groups & 686795.1 & 6 & 1114465.8 & 5.2 \\
\hline $\begin{array}{l}\text { Within groups } \\
\text { Total }\end{array}$ & 611896 & $\begin{array}{l}28 \\
34\end{array}$ & 21853 & \\
\hline
\end{tabular}

Table 2: Mean sum of squares (variance estimate)

$\mathrm{F}$ table at $5 \%$ level for $\mathrm{V}_{1}=6$

$$
\mathrm{V}_{2}=28=2.44
$$

$\mathrm{H}_{0}: \mathrm{X}_{1}=\mathrm{X}_{2}=\mathrm{X}_{3}=\mathrm{X}_{4}=\mathrm{X}_{5}=\mathrm{X}_{6}=\mathrm{X}_{7}$

$\mathrm{H}_{1}: \mathrm{X}_{1}=\mathrm{X}_{2}=\mathrm{X}_{3}=\mathrm{X}_{4}=\mathrm{X}_{5}=\mathrm{X}_{6}=\mathrm{X}_{7}$

decision rule

if $\left|\mathrm{F}_{\text {cal }}\right|>\left|\mathrm{F}_{\text {table }}\right|$ reject $\mathrm{H}_{0}$ and accept $\mathrm{H}_{1}$

if $\left|\mathrm{F}_{\text {cal }}\right|<\left|\mathrm{F}_{\text {table }}\right|$ accept $\mathrm{H}_{0}$ and reject $\mathrm{H}_{1}$

$|5.2|>|2.44|$ we accept the alternate $\left(\mathrm{H}_{1}\right)$ that is, there is need for International Financial Reporting Standards for Small and Medium Enterprise in Nigeria. 
International Journal of Finance and Accounting

ISSN xxxx-xxxx (Paper) ISSN 2518-4113 (Online)

Vol.1, Issue 3 No.5, pp 79 - 94, 2016

\section{Test of Hypothesis 2}

Ho2: International Financial Reporting Standard has not help Small and Medium Enterprises managements in Nigeria to achieve its goals and objectives and, improve markets share.

Table 3: Test of Hypothesis 2

\begin{tabular}{|c|c|c|c|c|c|c|c|c|c|c|c|c|c|}
\hline \multicolumn{2}{|c|}{$\begin{array}{l}\text { Sole } \\
\text { proprietors }\end{array}$} & \multicolumn{2}{|c|}{ Partners } & \multicolumn{2}{|c|}{ Accountants } & \multicolumn{2}{|c|}{$\begin{array}{l}\text { Internal } \\
\text { auditors }\end{array}$} & \multicolumn{2}{|c|}{$\begin{array}{l}\text { Executive } \\
\text { directors }\end{array}$} & \multicolumn{2}{|c|}{$\begin{array}{l}\text { Finance } \\
\text { managers }\end{array}$} & \multicolumn{2}{|c|}{ other staff } \\
\hline$X$ & $X^{2}$ & $X$ & $X^{2}$ & $\mathrm{X}$ & $X^{2}$ & $X$ & $X^{2}$ & X & $X^{2}$ & $\mathrm{x}$ & $X^{2}$ & $\mathrm{x}$ & $X^{2}$ \\
\hline 82 & $\begin{array}{l}672 \\
4\end{array}$ & 33 & 1089 & 358 & $\begin{array}{l}12816 \\
4\end{array}$ & 91 & 8281 & 105 & $\begin{array}{l}1102 \\
5\end{array}$ & 130 & $\begin{array}{l}1690 \\
0\end{array}$ & 465 & 216225 \\
\hline 58 & $\begin{array}{l}336 \\
4\end{array}$ & 15 & 225 & 171 & 29241 & 40 & 1600 & 57 & 3249 & 48 & 2304 & 159 & 25281 \\
\hline 22 & 484 & 9 & 81 & 23 & 529 & 14 & 196 & 11 & 121 & 15 & 225 & 29 & 841 \\
\hline 6 & 36 & 11 & 121 & 12 & 144 & 8 & 64 & 15 & 225 & 12 & 144 & 19 & 361 \\
\hline 8 & 64 & 3 & 9 & 10 & $` 100$ & 3 & 9 & 2 & 4 & 5 & 25 & 7 & 49 \\
\hline $\begin{array}{l}\sum x \\
=176\end{array}$ & $\begin{array}{l}\sum \times 2 \\
=10 t\end{array}$ & $\begin{array}{l}\sum x \\
=71\end{array}$ & $\begin{array}{l}\sum \mathrm{x} 2= \\
1525\end{array}$ & $\begin{array}{l}\sum x \\
=574\end{array}$ & $\begin{array}{l}\sum x 2= \\
15817 \\
8\end{array}$ & $\begin{array}{l}\sum x= \\
15 \\
6\end{array}$ & $\begin{array}{l}\sum \times 2= \\
1015 \\
0\end{array}$ & $\begin{array}{l}\sum x= \\
190\end{array}$ & $\begin{array}{l}\sum \times 2 \\
=146\end{array}$ & $\begin{array}{l}\sum x \\
=210\end{array}$ & $\begin{array}{l}\sum \mathrm{x} 2 \\
=195\end{array}$ & $\begin{array}{l}\sum x \\
= \\
679\end{array}$ & $\begin{array}{l}\sum \times 2 \\
=24275\end{array}$ \\
\hline
\end{tabular}

Table 4: Test of Hypothesis 2 Contd.

Sole Partners Accountants Internal Executive Finance other proprietors auditors directors managers staff

\begin{tabular}{|c|c|c|c|c|c|c|c|c|}
\hline $\mathrm{N}$ & 5 & 5 & 5 & 5 & 5 & 5 & 5 & $\sum \mathrm{n}=35$ \\
\hline$\sum \mathrm{x}$ & 176 & 71 & 574 & 156 & 190 & 210 & 679 & $\sum \sum x=2056$ \\
\hline$\sum x^{2}$ & 10672 & 1525 & 158178 & 10150 & 14624 & 19598 & $\begin{array}{l}24275 \\
7\end{array}$ & $\begin{array}{l}\sum \sum x^{2} \\
=457504\end{array}$ \\
\hline$\sum x^{2} / n$ & 2134.4 & 305 & 31635.6 & 2030 & 2924.8 & 3919.6 & $\begin{array}{l}48551 \\
4\end{array}$ & $\begin{array}{l}\sum\left(\sum x^{2} / n\right)= \\
91500.8\end{array}$ \\
\hline
\end{tabular}


International Journal of Finance and Accounting

ISSN xxxx-xxxx (Paper) ISSN 2518-4113 (Online)

Vol.1, Issue 3 No.5, pp 79 - 94, 2016

$\sum \sum \mathrm{x}=451=\left(\sum \sum \mathrm{x}\right)^{2}=457504 \quad \therefore\left(\sum \sum \mathrm{x}\right)^{2} / \mathrm{n}=457504 / 35=13071.5$

Formula for between groups sum of squares

$\sum\left(\sum \mathrm{x}\right)^{2}-\left(\sum \mathrm{x}\right)^{2}$

n

$\mathrm{n}$

$\therefore$ 457504-13071.5=444432.5

Formula for within group sum of squares

$\sum \sum \mathrm{x}^{2}-\sum\left(\sum \mathrm{x}\right)^{2}$

$\mathrm{n}$

$457504-91500=366004$

Degree of freedom $(\mathrm{df})=\mathrm{K}-1$ (number of groups minus one)

$\therefore 7-1=6$

Degree of freedom (df) for within groups $=\mathrm{N}-\mathrm{K}$ (total number of respondents in the groups minus number of groups)

$\therefore 35-7=28$

Degree of freedom (df) for total variance $=\mathrm{N}-1$ (total number of respondents in the groups minus one). .. $35-1=34$

Mean sum of squares (variance estimate)

$=\underline{444432.5}$

$6=74072.1$

Within group mean square

$=\underline{366004}$

$28=13071.6$

$\mathrm{F}-$ ratio $=\underline{74072.1}$

$13071.6=5.7$ 
Table 5: Test of Hypothesis 2 Contd.

\begin{tabular}{|c|c|c|c|c|c|}
\hline $\begin{array}{l}\text { source } \\
\text { variation }\end{array}$ & sum of squares & $\begin{array}{l}\text { Degree } \\
\text { freedom }\end{array}$ & of & $\begin{array}{l}\text { Mean sum of } \\
\text { squares variation }\end{array}$ & $\mathrm{F}$ \\
\hline Between groups & 444432.5 & 6 & & $74072.1=$ & 5.7 \\
\hline $\begin{array}{l}\text { Within groups } \\
\text { Total }\end{array}$ & $\begin{array}{l}366004 \\
810436.5\end{array}$ & $\begin{array}{l}28 \\
34\end{array}$ & & 13071.6 & \\
\hline
\end{tabular}

F table at $5 \%$ level for $\mathrm{V}_{1}=6$

$$
\mathrm{V}_{2}=28=2.44
$$

$\mathrm{H}_{0}: \mathrm{X}_{1}=\mathrm{X}_{2}=\mathrm{X}_{3}=\mathrm{X}_{4}=\mathrm{X}_{5}=\mathrm{X}_{6}=\mathrm{X}_{7}$

$\mathrm{H}_{1}: \mathrm{X}_{1}=\mathrm{X}_{2}=\mathrm{X}_{3}=\mathrm{X}_{4}=\mathrm{X}_{5}=\mathrm{X}_{6}=\mathrm{X}_{7}$

decision rule

if $\left|\mathrm{F}_{\text {cal }}\right|>\left|\mathrm{F}_{\text {table }}\right|$ reject $\mathrm{H}_{0}$ and accept $\mathrm{H}_{1}$

if $\left|\mathrm{F}_{\text {cal }}\right|<\left|\mathrm{F}_{\text {table }}\right|$ accept $\mathrm{H}_{0}$ and reject $\mathrm{H}_{1}$

$|5.7|>|2.44|$ we accept the alternate $\left(\mathrm{H}_{1}\right)$ that is, International Financial Reporting Standard has helped Small and Medium Enterprises managements in Nigeria to achieve its goals and objectives and, improve markets share.

\section{Test of Hypothesis 3}

Ho3: Non-compliance with International Financial Reporting Standards does not constitute a challenge to Small and Medium Enterprises in Nigeria.

Table 6: Test of Hypothesis 3

\begin{tabular}{|c|c|c|c|c|c|c|c|c|c|c|c|c|c|}
\hline \multicolumn{2}{|c|}{$\begin{array}{l}\text { Sole } \\
\text { proprietors }\end{array}$} & \multicolumn{2}{|c|}{ Partners } & \multicolumn{2}{|c|}{ Accountants } & \multicolumn{2}{|c|}{$\begin{array}{l}\text { Internal } \\
\text { auditors }\end{array}$} & \multicolumn{2}{|c|}{$\begin{array}{l}\text { Executive } \\
\text { directors }\end{array}$} & \multicolumn{2}{|c|}{$\begin{array}{l}\text { Finance } \\
\text { managers }\end{array}$} & \multicolumn{2}{|c|}{ other staff } \\
\hline $\mathrm{X}$ & $\mathrm{X}^{2}$ & $\mathrm{x}$ & $\mathrm{X}^{2}$ & $\mathrm{X}$ & $\mathrm{X}^{2}$ & $\mathrm{X}$ & $\mathrm{X}^{2}$ & $\mathrm{x}$ & $\mathrm{X}^{2}$ & $\mathrm{x}$ & $\mathrm{X}^{2}$ & $\mathrm{X}$ & $\mathrm{X}^{2}$ \\
\hline 46 & 2116 & 19 & 361 & 182 & 33124 & 38 & 1444 & 48 & 2304 & 60 & 3600 & 192 & 36864 \\
\hline & 676 & & 64 & 48 & 2304 & 20 & 400 & 24 & 576 & 38 & 1444 & 105 & 11025 \\
\hline 3 & 9 & 2 & 4 & 3 & 9 & 3 & & & & & 4 & 17 & 289 \\
\hline & 81 & 7 & 49 & 87 & 7569 & 18 & 324 & 16 & 256 & 15 & 225 & 49 & 2401 \\
\hline & 256 & 5 & 25 & 23 & 529 & 13 & 169 & 14 & 196 & & & 28 & 784 \\
\hline$\sum x=100$ & $\sum x 2$ & $\sum_{=41} x$ & $\sum x 2=$ & $\begin{array}{l}\sum x \\
=343\end{array}$ & $\sum \mathrm{x} 2=$ & $\sum x=$ & $\sum \mathrm{x} 2=$ & $\sum x=$ & $\sum \mathrm{x} 2$ & $\sum x$ & $\sum x 2$ & $\sum x=$ & $\sum x 2$ \\
\hline & $=3138$ & & & & & & & & $=3357$ & $=120$ & $=5298$ & & $=51363$ \\
\hline
\end{tabular}


International Journal of Finance and Accounting

ISSN xxxx-xxxx (Paper) ISSN 2518-4113 (Online)

Vol.1, Issue 3 No.5, pp 79 - 94, 2016

Table 7: Test of Hypothesis 3 Contd.

\begin{tabular}{lllllllll}
\hline & $\begin{array}{l}\text { Sole } \\
\text { proprietors }\end{array}$ & Partners & Accountants & $\begin{array}{l}\text { Internal } \\
\text { auditors }\end{array}$ & $\begin{array}{l}\text { Executive } \\
\text { directors }\end{array}$ & $\begin{array}{l}\text { Finance } \\
\text { managers }\end{array}$ & $\begin{array}{l}\text { other } \\
\text { staff }\end{array}$ & \\
\hline $\mathrm{N}$ & 5 & 5 & 5 & 5 & 5 & 5 & 5 & $\sum \mathrm{n}=35$ \\
$\sum \mathrm{x}$ & 100 & 41 & 343 & 92 & 107 & 120 & 391 & $\sum \sum \mathrm{x}=1194$ \\
$\sum \mathrm{x}^{2}$ & 3138 & 503 & 43535 & 2346 & 3357 & 5398 & 51363 & $\sum \sum \mathrm{x}^{2}=109640$ \\
$\sum \mathrm{x}^{2} / \mathrm{n}$ & 627.6 & 100.6 & 8707 & 469.2 & 671.4 & 1079.6 & 102726 & $\sum\left(\sum \mathrm{x}^{2} / \mathrm{n}\right)=21928$ \\
\hline
\end{tabular}

$\sum \sum x=1194=\left(\sum \sum x\right)^{2}=109640 \therefore\left(\sum \sum x\right)^{2} / n=109640 / 35=3132.6$

Formula for between groups sum of squares

$\sum\left(\sum \mathrm{x}\right)^{2}-\left(\sum \mathrm{x}\right)^{2}$

n n

$\therefore 109640-3132.6=106507.4$

Formula for within group sum of squares

$$
\sum \sum \mathrm{x}^{2}-\frac{\sum\left(\sum \mathrm{x}\right)^{2}}{\mathrm{n}}
$$

$109640-21928=87712$

Degree of freedom $(\mathrm{df})=\mathrm{K}-1$ (number of groups minus one)

$\therefore 7-1=6$

Degree of freedom (df) for within groups $=\mathrm{N}-\mathrm{K}$ (total number of respondents in the groups minus number of groups)

$\therefore 35-7=28$

Degree of freedom (df) for total variance $=\mathrm{N}-1$ (total number of respondents in the groups minus one). $\therefore .35-1=34$

Mean sum of squares (variance estimate)

$=\underline{106507.4}$

$6=17751.2$

Within group mean square

$=\underline{87712}$

$$
\begin{gathered}
28=3132.6 \\
\mathrm{~F}-\text { ratio }=\frac{17751.2}{3132.6}=5.7
\end{gathered}
$$


Table 8: Test of Hypothesis 3 Contd.

\begin{tabular}{llllll}
\hline $\begin{array}{l}\text { source of } \\
\text { variation }\end{array}$ & sum of squares & $\begin{array}{l}\text { Degree } \\
\text { freedom }\end{array}$ & of & $\begin{array}{l}\text { Mean sum of } \\
\text { squares variation }\end{array}$ & F \\
\hline Between groups & 106507.4 & 6 & 17751.2 & 5.7 \\
& & & & & \\
Within groups & 87712 & 28 & 3132.6 & \\
Total & 194219.4 & 34 & & \\
\hline
\end{tabular}

F table at $5 \%$ level for $\mathrm{V}_{1}=6$

$$
\mathrm{V}_{2}=28=2.44
$$

$\mathrm{H}_{0}: \mathrm{X}_{1}=\mathrm{X}_{2}=\mathrm{X}_{3}=\mathrm{X}_{4}=\mathrm{X}_{5}=\mathrm{X}_{6}=\mathrm{X}_{7}$

$\mathrm{H}_{1}: \mathrm{X}_{1}=\mathrm{X}_{2}=\mathrm{X}_{3}=\mathrm{X}_{4}=\mathrm{X}_{5}=\mathrm{X}_{6}=\mathrm{X}_{7}$

decision rule

if $\left|\mathrm{F}_{\text {cal }}\right|>\left|\mathrm{F}_{\text {table }}\right|$ reject $\mathrm{H}_{0}$ and accept $\mathrm{H}_{1}$

if $\left|\mathrm{F}_{\text {cal }}\right|<\left|\mathrm{F}_{\text {table }}\right|$ accept $\mathrm{H}_{0}$ and reject $\mathrm{H}_{1}$

5.7> 2.44 we accept the alternate $\left(\mathrm{H}_{1}\right)$ that is, Non-compliance with International Financial Reporting Standards constitute a challenge to Small and Medium Enterprises in Nigeria.

\section{CONCLUSION}

The study was carried out to examine the different between IFRS and SAS and Full IFRS and IFRS for SMEs, implementation/compliance, benefit and challenges as it faces Nigeria from perceptive of the accountants of small businesses. Research show that IFRS for SMEs is relevant for SMEs in Nigeria as small businesses in Nigeria stand to enjoy easy access to international investments and investors, bank loans, high rating by international credit rating agencies. All due there are several challenges that can distort the effective implementation of IFRS for SMEs in Nigeria if the major stakeholders in accounting profession such as financial reporting council of Nigeria (FRCN), the institute of chartered accounting of Nigeria (ICAN), and association of national accountants of Nigeria (ANAN) did not intervene urgently.

\section{RECOMMENDATIONS}

This study recommends that the IASB should ensure full implementation/compliance of IFRS for SME by companies that fall under that category, the cost of acquiring IFRS education should also be subsidized for small firms by major accounting regulatory bodies in Nigeria.

The regulatory of accounting practice in Nigeria should increase the level of awareness among managers, investors and other major stakeholders on the merits of adopting the IFRS to enhance the degree of compliance with the Financial Reporting and Accounting Requirement. 


\section{REFERENCES}

Agoglia, C. P., Doupnik, T. S. \&Tsakumis, G. T. (2011). Principles-based versus rule-based accounting standards: The influence of standard precision and audit committee strength on financial reporting decisions. The Accounting review, 86, 747,

Akindele, A.O. (2012).The impacts of international financial reporting standards adoption on financial statements: The case of Nigeria. Journal of Business Economics and Tourism, vaasa university of applied science, $9(5)$.

Akintola, O. (2012). Adopting international financial reporting standards (IFRS) in Africa: benefits, prospects and challenges. African J. Accounting, Auditing and Finance, 1(1), 77.

Aremu M. A.,and Adeyemi S. L. (2011), Small and Medium Scale Enterprises as A Survival Strategy for Employment Generation in Nigeria .Research Journal of Finance and Accounting: 4(1).

Callao, S. J., Jarne, G.K., \&La'inez, C. B. (1995). International capital market pressures and voluntary annual report disclosures by U.S. and U.K. multinationals. Journal of International Financial Management and Accounting, 6(I), 43 - 68.

Darrel scott; Board member, chairman of the SME Implementation Group and Michelle Fisher; Senior Technical jmanager, IFRS for SMEs.

Eke, P. O., Onafalujo, A.K. and Akinlabi, B. H. (2011). Impact of International Financial (_/Reporting Standards on Insurance Management in Nigeria. Middle Eastern Financeand Economics ISSN: 1450-2889: 12.

Ekpenyong, D.B. and Nyong, M. O. (1992). Small and Medium-Scale Enterprises in Nigeria: Their characteristics, problems and sources of finance. African Economic Research Consortium. Research Paper sixteen.

Ekwem, Ijeoma (2012), Small and medium scale enterprises development in Nigeria : Constraints and policy options Research report presented in partial fulfillment of the requirements for the degree of Master of Development Finance at the University of Stellenbosch 
Ezeani, N. S. and Oladele R. (2012), adoption of international financial reporting standard (IFRS) to enhance financial reporting in Nigeria universities. Arabian Journal of Business and Management Review (OMAN Chapter) 2 (3), 70.

Fowokan, T. (2011). IFRS Adoption in Nigeria -Tax Implications. Paper presented at CITN Seminar on IFRS Adoption in Nigeria.

Gyasi, A. (2010). Adoption of International Financial Reporting Standards in Developing L,' Countries - The Case of Ghana. Business Economics and Tourism.

Glaum, M., \& Street, D. L. (2003). Compliance with the disclosure requirements of Germany's new market: IAS versus US GAAP. Journal of International Financial Management and Accounting, 14 (1), 64- 100.

Holt, G. (2009). IFRS for SMEs.retrieved January 23,2012 from http://www.ifrs.org

IASB (2007) Exposure draft on the proposed JFRS for small and medium sized Entities. London: IASB.

IFRS Foundation; Training Material for the IFRS for SMEs (version 2013-1)http//www. iosrjournals. Org

Kanu, C., Onuoha N., and Egwu,, G.I.(2014),

KPMG LLP (2009). Issues In-Depth. August No. 09(2).

Lagos Chamber of Commerce and Industry (2012). Small and Medium Enterprises and Distributive Group. Retrieved 22 March, 2012 from http://www.lagoschamber,com/index2.php?page=sectoralb X Nigerian Accounting Standard Board. (2010). Report of the Committee on Road Map to the Adoption of International Financial Reporting Standards in Nigeria. Retrieved 18 Nov, 2011 from fJittp:/Avww.nasbnigeria.org/attachments/articIe/83/Roadmap\%20FinaI\%20Report\%20S eptember\%202010.pdf -, 
Lagos Chamber of Commerce and Industry (2012). Small and Medium Enterprises and Distributive $\quad$ Group. $\quad$ Retrieved 22 March, 2012 fromhttp://www.lagoschamber.com/index2.php7page sectoral

Minisola B. (2005\}, Challenges of Small and Medium Enterprises in Nigeria. Conference paper

Nobes C, Parker R. (2004). Comparative International Accounting, Prentice Hal], 2004.

Nigerian accounting standard board. (2010). Report of the committee on road map to the adoption of international ficnail reporting standards in Nigeria. Retrieved 18 nov. 2011 from http://www.nasbnigeria.org/attachments/article/83/roadmap\%20final\%20reprot\%20sepe mber\%202010.pdf.

Nwachukwu, I. (2014, April 2). IFRS challenge forces coys to delay FY'13 results submission.Business Day, 1, 4.

Odia,.J.O. and Ogiedu, K.O. (2013). IFRS Adoption : Issues, Challenges and Lessons for Nigeria and other Adopters .Mediterranean Journal of Social Sciences. 4( 3), 389-400.

Olanrewaju, OluseyiOladimeji: IFRS PAL. Handy Approach ( IFRS)

OnyinyeOyeokaIfeoma, Adetula D.T. and Owolabi, Folasshade; Department of Accounting, Covenant University, Ota,Ogun State, Nigeria.

PricewaterhouseCoopers (2009). IFRS for small and medium-sized entities. Pocket Guide 2009. Retrieved January 22, 2012 from http://www.pwc.com.

PricewaterhouseCoopers, (2003), Illuminating Values: The Business Impact of IFRS \{online]. Available: hap,' Ivww.pwcgIobaJ.com

Winney, K., Marshall, D., Bender, B. and Swiger, J. (2010). Accounting Globalization: Roadblocks to IFRS Adoption in the United States. Global Review of Accounting and Finance. 1(1),167-178. 